This PDF is a selection from a published volume from the National Bureau of Economic Research

Volume Title: Managing Currency Crises in Emerging Markets

Volume Author/Editor: Michael P. Dooley and Jeffrey A.

Frankel, editors

Volume Publisher: University of Chicago Press

Volume ISBN: 0-226-15540-4

Volume URL: http://www.nber.org/books/dool03-1

Conference Date: March 28-31, 2001

Publication Date: January 2003

Title: The International Lender of Last Resort. How Large Is Large Enough?

Author: Olivier Jeanne, Charles Wyplosz

URL: http://www.nber.org/chapters/c9649 


\section{The International Lender of Last Resort \\ How Large Is Large Enough?}

Olivier Jeanne and Charles Wyplosz

\subsection{Introduction}

The Asian crises have triggered a debate on how new rules and institutions could increase the resilience of the international monetary system. Among many proposals, it has been suggested that an international lender of last resort would be a useful addition. One idea, a distant reminder of Keynes's proposal in Bretton Woods, is to set up an international central bank that would issue a global currency (Garten 1998). Other ideas start from the observation that crisis lending by the international community has already evolved toward de facto lending in last resort since the Mexican bailout - a trend that, some argue, should be developed and institutionalized (Fischer 1999). A report to the U.S. Congress recently advocated the transformation of the International Monetary Fund (IMF) into a "quasi-lender of last resort" lending at penalty rates and against good marketable collateral (International Financial Institution Advisory Commission [IFIAC] 2000). Others have argued that the international lending-in-last-resort function should be un-

Olivier Jeanne is a researcher at the International Monetary Fund. Charles Wyplosz is professor of international economics at the Graduate Institute of International Studies.

For helpful comments on the previous versions, the authors thank participants in the NBER conference, and especially our discussant, Olivier Blanchard. The authors also thank Philippe Bacchetta, Patrick Bolton, Peter Clark, Daniel Cohen, Giovanni Dell'Ariccia, Enrica Detragiache, Piti Disyatat, Stanley Fischer, Gerhard Illing, Peter Isard, Christian Mulder, John Pattison, Pascal Rousseau, Alexander Swoboda, and participants at seminars at the Graduate Institute of International Studies, Humboldt University, the International Monetary Fund, the fifth annual meeting of the Latin American and Caribbean Economic Association, and the National Bank of Switzerland for helpful comments and discussions. This paper reflects the views of its authors, which are not necessarily those of the IMF. 
dertaken by the Bank of International Settlements (BIS; Fratianni and Pattison 2001).

The idea that an international lender of last resort (LOLR) could and should become the linchpin of the global financial architecture has been criticized on different grounds. It has been noted, first, that an international LOLR might worsen the moral hazard problem, which, some argue, is one of the main causes of fragility of the international financial system (Calomiris 1998). Another argument is that although a true international lender of last resort might be desirable in theory, it has no chance of being instituted in practice because the institutional changes involved go well beyond what the international community is ready to accept (Eichengreen 1999). Some further claim that an international LOLR cannot function effectively unless it can issue an indefinite amount of its own currency (Capie 1998), and others argue that the LOLR would need an amount of hard currencies that, although finite, is unrealistically large (Eichengreen 1999; Rogoff 1999).

The debate suggests that the notion of an international LOLR is not well understood, or at least is subject to different interpretations. Questions range from the nature of crises to the arrangements required for the LOLR to operate. ${ }^{1}$ This paper proposes a formal framework that may help shed light on several of these issues.

The question with which this paper is primarily concerned is that of the size of the international LOLR. Does the international LOLR have to be a global central bank, or could it function effectively as a fund with limited and predetermined resources? In the second case, how large should the fund be? To answer these questions, we build a model of an emerging economy that is vulnerable to international liquidity crises. An international LOLR can in principle cope with these crises by providing hard currency to cashstrapped countries. We scrutinize the size of LOLR interventions that are required to that effect.

This paper focuses on the effectiveness of an international LOLR in dealing with twin (banking and currency) crisis. ${ }^{2}$ The need for an international LOLR stems, in our model, from a currency mismatch in the balance sheet of the emerging economy's banking sector. The domestic banking sector does not hold enough foreign currency assets to cover its short-term foreign

1. This lack of consensus reflects, to some extent, the state of the literature on the lendingin-last-resort doctrine. Indeed, the dominant genre in this literature seems to be the exegesisthe spirit and letter of Bagehot's Lombard Street being invoked to promote various interpretations of the "classical" doctrine. The more formal (model-based) literature, which is generally based on variants of the Diamond-Dybvig model, fails to capture many insights of its less formal counterpart. Naturally, the transposition of these debates to the international context makes things more difficult. See Freixas and Rochet (1997, chap. 7) or Bordo (1990) for reviews of the main debates on lending in last resort.

2 . The role of the international LOLR in connection with sovereign liquidity crises is discussed by Sachs (1995), Jeanne (2000b), and Kumar, Masson, and Miller (2000). 
currency liabilities. ${ }^{3}$ It is vulnerable, as a result, to panics in which shortterm creditors withdraw their credit lines and depositors run on domestic banks. As in some recent models of twin crises, these panics can be selffulfilling because of the two-way feedbacks between the depreciation of the currency and the deterioration of banks' balance sheets (Burnside, Eichenbaum, and Rebelo 1999; Schneider and Tornell 2000).

The question, then, is how large the international LOLR should be to remove the bad equilibrium. We find that the required size of the international LOLR crucially depends on how its resources are used. We compare two approaches, which correspond to the distinction-originally made by Goodfriend and King (1988) in a domestic context - between "lending-inlast-resort as an input in monetary policy" and "lending-in-last-resort as an input in banking policy." In the former approach, the international LOLR injects its resources into the financial market, directly or through the domestic monetary authorities. In the second approach, the resources of the international LOLR are used to back domestic banking safety nets, such as discount-window lending policy by the central bank or a government guarantee of banks' foreign currency liabilities. The two approaches have the following implications for the size of the international LOLR.

- If the resources of the international LOLR are injected into the market, lending in last resort has to be carried out by the issuer of the international currency (the U.S. Federal Reserve). The panic equilibrium is not removed by a limited fund, even a very large one.

- The lending-in-last-resort function can be effectively carried out by a limited fund if its resources are used to back domestic banking safety nets. Then the international LOLR resources do not need to be larger than the liquidity gap in the domestic banking sector, that is, the difference between the domestic banking sector's short-term foreign currency liabilities and its foreign currency liquid assets.

Clearly, the second approach seems more practical than the first one. We argue, however, that it raises knotty agency problems that seem difficult to address under the current international financial architecture. In the second approach, the international LOLR would have to be an "International Banking Fund" closely integrated with the domestic systems of financial safety nets and supervision in emerging economies. It would have to assume a significant role in supervising domestic banking sectors. We do not see such an evolution as likely, at least in the foreseeable future. Nations remain jealous of their prerogatives in the regulation and supervision of their banking sectors, and there seems to be little political appetite for a globally inte-

3. If the assets and liabilities of domestic banks were denominated in the domestic currency, the domestic authorities would not need any external assistance to lend in last resort (Chang and Velasco 2000; Goodhart and Huang, 2000). There would be no need for an international lender of last resort. 
grated system with the IMF, the BIS, or any new institution at its center (Eichengreen 1999; Giannini 2002).

As a by-product, our model yields interesting insights on monetary policy and exchange rate regimes in emerging economies. In particular, we find that the country's vulnerability to twin crises is the same under a flexible exchange rate regime as under a fixed peg. The reason is that the scope offered by exchange rate flexibility is largely illusory in a twin crisis. A floating exchange rate regime allows the domestic monetary authorities to set lower interest rates, but the associated exchange rate depreciation is no less destabilizing for the domestic financial sector - when there is a currency mismatch - than high interest rates. ${ }^{4}$ Indeed, if our analysis has any implications for exchange rate regimes, it is to suggest the optimality of very hard pegs, or dollarization. In our model, a credible commitment not to devalue the currency removes the bad equilibrium at no cost to the international community.

The paper is structured as follows. Section 4.2 presents some evidence on the Asian crises to motivate the model. Section 4.3 presents the model. Section 4.4 examines the role of domestic monetary policy, and section 4.5 that of an international lender of last resort. Section 4.6 concludes.

\subsection{The Asian Twin Crises: Some Stylized Facts}

Although the concomitance of banking and currency crises is not an original feature of the Asian 1997 crisis, ${ }^{5}$ it appeared as a very salient one for market participants at the time. Market analysts generally viewed the banking crises as the primary determinant of the currency instability and conditioned their exchange rate forecasts on the prospects of a recovery in the banking sector (see, e.g., the Financial Time Currency Forecaster 199798). This section presents a few stylized facts on the banking and currency crises in the four countries most affected by banking instability: Indonesia, Korea, Malaysia, and Thailand. Our main purpose is to motivate the assumptions of the model presented in the following section.

\subsubsection{Maturity and Currency Mismatches}

The four crisis-hit countries received an exceptionally high level of capital inflows in the period leading up to the crisis. A significant fraction of these inflows took the form of short-term credit in foreign currency. Meanwhile, current account deficits were draining the foreign exchange reserves, leading to the buildup of a large and increasing gap between short-term external debt and the foreign exchange reserves at the central bank (fig. 4.1). On the eve of the crisis, only Malaysia had enough reserves to cover its

4. A similar point is made by Bacchetta (2000) and Aghion, Bacchetta, and Banerjee (2000). See also Céspedes, Chang, and Velasco (2000); Christiano, Gust, and Roldos (2000); and Gertler, Gilchrist, and Natalucci (2000) for recent models of monetary policy with a balance sheet channel for the exchange rate.

5. Kaminsky and Reinhart (1999) count nineteen twin crises prior to 1995. 

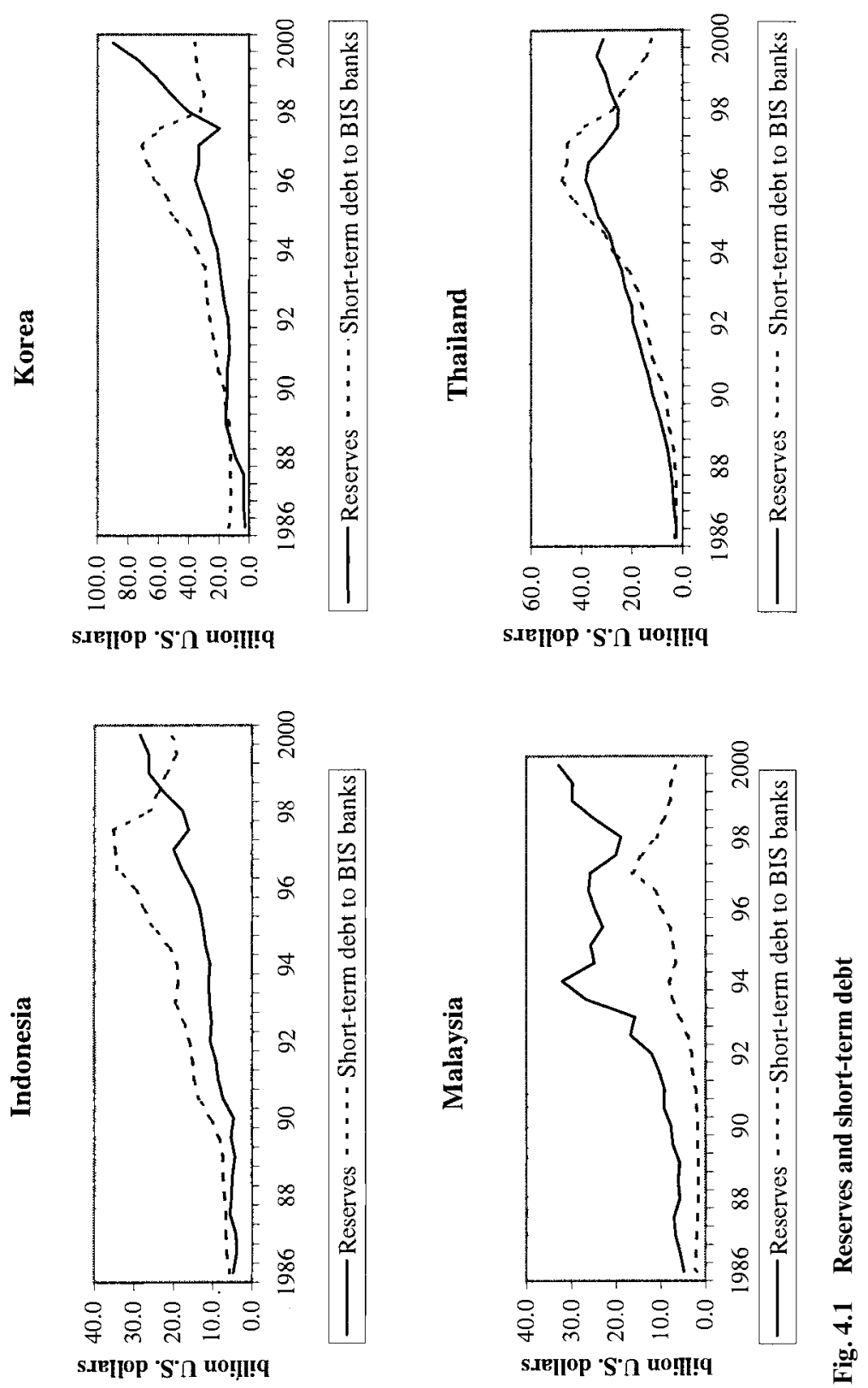
Table 4.1

The Asian Twin Crises

\begin{tabular}{lcccc}
\hline & Indonesia & Korea & Malaysia & Thailand \\
\hline $\begin{array}{l}\text { Foreign exchange reserves } \\
\quad \text { (end of 1996) }\end{array}$ & 7.8 & 6.4 & 26.0 & 20.5 \\
$\begin{array}{l}\text { Short-term debt to } \\
\quad \text { BIS-reporting banks } \\
\quad \text { (end of 1996) }\end{array}$ & & & & \\
$\begin{array}{l}\text { Foreign liabilities of } \\
\quad \text { domestic banks } \\
\quad \text { (end of 1996) }\end{array}$ & 15.0 & 12.0 & 11.2 & 25.1 \\
$\begin{array}{l}\text { Peak-to-trough decline in } \\
\quad \text { reserves }\end{array}$ & 5.6 & 8.7 & 11.2 & 27.1 \\
$\begin{array}{l}\text { Decline in domestic banks } \\
\quad \text { foreign liabilities }\end{array}$ & $(6 / 97-2 / 98)$ & $(7 / 97-12 / 97)$ & $(3 / 97-1 / 98)$ & $(1 / 97-8 / 97)$ \\
$\begin{array}{l}\text { Liquidity support to financial } \\
\quad \text { institutions (6/97-6/99) }\end{array}$ & $(6 / 97-2 / 98)$ & $(7 / 97-12 / 97)$ & $(3 / 97-1 / 98)$ & $(1 / 97-8 / 97)$ \\
$\begin{array}{l}\text { IMF-supported packages } \\
\quad \text { disbursement) }\end{array}$ & 31.9 & 6.9 & 13.8 & 22.5 \\
$\begin{array}{l}\text { Bank closures (percentage points } \\
\quad \text { of total banking assets) }\end{array}$ & 8.8 & 6.0 & - & 7.9 \\
$\begin{array}{l}\text { Memorandum items } \\
\quad \text { Total bank assets (1996) }\end{array}$ & 18.0 & 15.0 & 0.0 & 13.0 \\
$\quad$ 1996 GDP (US\$ billions) & 90.0 & 300.0 & 300.0 & 190.0 \\
\hline
\end{tabular}

Note: The variables are expressed in percentage points of 1996 GDP, except when specified otherwise.

short-term debt to BIS-reporting banks. The international liquidity gap was especially large in Indonesia, where it exceeded 7 percent of gross domestic product (GDP) at the end of 1996 (table 4.1). A significant fraction of this buildup in short-term external debt reflected borrowing by domestic banks. The foreign liabilities of domestic banks increased markedly in all countries, most dramatically in Thailand, where they were approaching one third of GDP on the eve of the crisis (table 4.1).

Most of the external borrowing by banks and corporates was denominated in foreign currency, and the resulting currency risk was largely unhedged. Data limitations make it very difficult to assess the extent to which the currency risk was assumed directly by banks or passed along to their borrowers. Although bank regulation typically disallows currency mismatches, one of the lessons from the recent crises is that they do occur and can be sizable. Even when the banks themselves avoid currency mismatches, firms that are their customers may carry such a risk on their own books. If many large firms fail simultaneously, so will their banks, especially as maturity transformation is a key function of the banking system.

\subsubsection{The Bust}

The crisis was accompanied by sharp depreciations of the exchange rate in all countries, a phenomenon that was more pronounced and persistent in 
Indonesia than elsewhere (fig. 4.2). Indonesia was also exceptional in the level at which it raised its interest rate, a difference that reflected more the burst of inflation that followed the depreciation than an aggressive defense of the currency (fig. 4.3). By contrast, the interest rates in Malaysia seem to have been somewhat insulated from exchange rate developments by capital controls.

Simultaneously, the banking problems that had started to surface before the crisis took a sudden turn for the worse under the joint pressure of high interest rates, a depreciated currency, and a general loss of confidence. The currency depreciation had an adverse effect on the solvency of banks and firms because of the currency mismatches in their balance sheets. A largescale run by domestic depositors was observed in Indonesia, where, by midDecember 1997, 154 banks representing half of the total assets of the system had faced a significant erosion of their deposit base (Lindgren et al. 1999). The other countries had to cope with a similar pressure coming from short-term creditors, especially foreign banks in Korea.

Although the withdrawal of foreign credit lines certainly exercised a drain on the foreign exchange reserves, it does not seem to have been in general the primary cause of capital outflows. Table 4.1 reports peak-to-trough

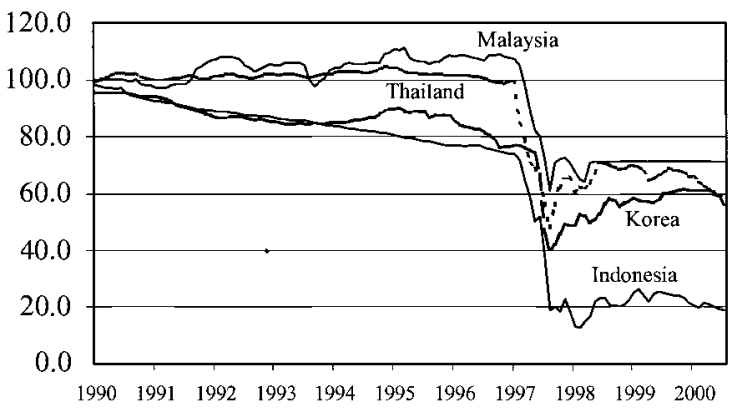

Fig. 4.2 Exchange rates (1990-2000)

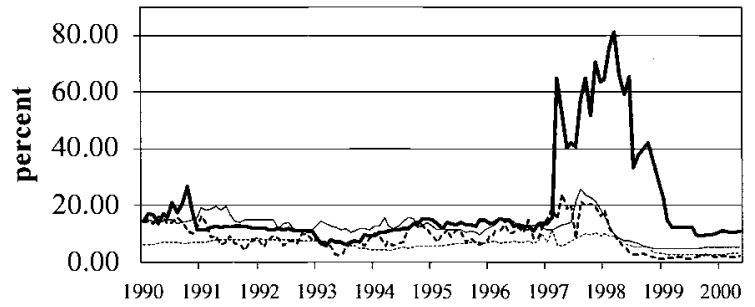

$$
\begin{array}{|l|}
\text { - INDONESIA - KOREA } \\
\text { MALAYSIA } \\
-\cdots
\end{array}
$$

Fig. 4.3 Money market interest rates 


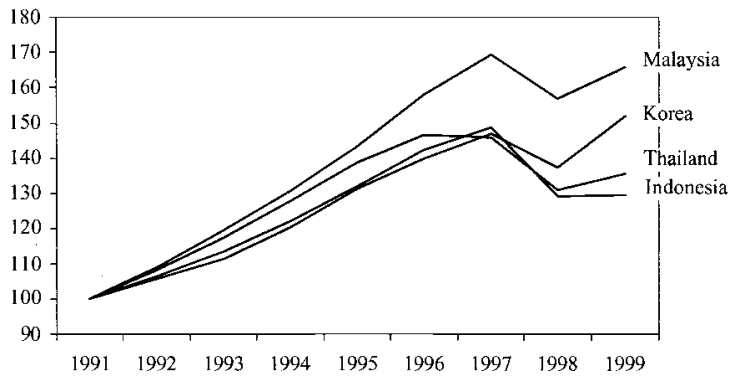

Fig. 4.4 Real GDP $(1991=100)$

changes in foreign exchange reserves, as well as the change in the foreign liabilities of domestic banks at the time of the crisis. With the exception of Korea, the drop in reserves was driven much more by speculative capital outflows than by the repayment of banks' foreign debt. On average (excluding Korea), the fall in reserves was six times as large as the decline in banks' foreign liabilities. In other words, out of each dollar flowing out of these economies, less than fourteen cents were used to repay the foreign liabilities of domestic banks. The rest was capital flight caused by domestic and foreign residents' shifting their portfolio toward foreign assets and by speculation against the domestic currency.

The four countries suffered large falls in output (see fig. 4.4) and there is evidence that the banking problems contributed to the slumps. The importance of banks in financial intermediation had increased markedly in the period leading up to the crisis. ${ }^{6}$ As the crisis developed, the most insolvent banks were closed, and the others saw their ability to lend curtailed by the withdrawal of short-term credit lines. Banking problems were associated with a severe decline in real credit (Lindgren et al. 1999). Although it is delicate, as always, to disentangle the respective contributions of demand and supply in the credit crunch, some studies have found evidence that it was in part supply driven (Ghosh and Ghosh 1999; Ding, Domaç, and Ferri 1998).

\subsubsection{Policy Responses}

Countries responded to the crisis on several fronts. We briefly review the emergency measures in macro and banking policies, leaving aside the more structural policies that were also initiated at the time of the crisis.

The first and most immediate decision in a currency crisis is the choice between increasing the interest rate in order to defend the currency and letting the exchange rate go. Our four countries did both to various extents, in

6. Total commercial bank and near-bank assets grew from between 50 and 100 percent of GDP in 1992 to between 150 and 200 percent of GDP at the end of 1996 (see table 4.1). As a comparison, deposit money banks held assets equal to 80 percent of GDP in the United States. 
part as the reflection of a dilemma in which the monetary authorities were caught. On the one hand, there were limits to which the interest rate could be raised, given the fragile state of the banking and corporate sectors. On the other hand, letting the currency depreciate also had adverse effects because of the currency mismatch in the balance sheets of banks and firms.

The limited scope offered by monetary policy led the authorities to rely on policies that were more directly targeted at banks. In all four countries central banks provided liquidity to financial institutions under various emergency lending and LOLR facilities. The amounts were especially large in Indonesia and Thailand, where they exceeded 20 percent of GDP (table 4.1). This liquidity support was provided in domestic currency except in Korea, where it was primarily in U.S. dollars. To the extent that its impact on the monetary base was sterilized, however, the liquidity support provoked the same reserves losses irrespective of the currency in which it was provided. ${ }^{7}$

The provision of emergency liquidity was enhanced by various forms of government guarantees of banks' liabilities. None of the four countries had a formal insurance scheme on bank deposits at the beginning of the crisis, so the guarantees had to be introduced under the pressure of events. As the severity of the crisis became apparent and the introduction of more limited guarantees failed to restore confidence, the four countries ended up providing blanket guarantees for all depositors and most creditors (Lindgren et al. 1999). The guarantees did not always succeed in stemming capital outflows, however, possibly because of uncertainty about the government's ability to honor them. In Korea, for example, the guarantee on foreign debt was not sufficient to convince short-term foreign creditors to roll over their credit lines. This was followed by an effort to coordinate creditors and was resolved by voluntary debt restructuring. In all four countries, the guarantees were announced to be temporary and meant to maintain public confidence during the period of restructuring.

These policies were backed by large rescue packages arranged under the auspices of the IMF, with the notable exception of Malaysia. Interestingly, the size of these packages was of the same order of magnitude as - and in fact slightly larger than-the liquidity gap before the crisis (table 4.1). Malaysia instead chose to introduce drastic capital controls.

\subsection{Model}

One feature of twin crises that the Asian experience illustrates very well is the mutually self-reinforcing nature of banking and currency fragilities. As Kaminsky and Reinhart (1999) put it, "Financial-sector problems

7. Sterilization was largely effective in Korea and Thailand, but not in Indonesia and Malaysia. 


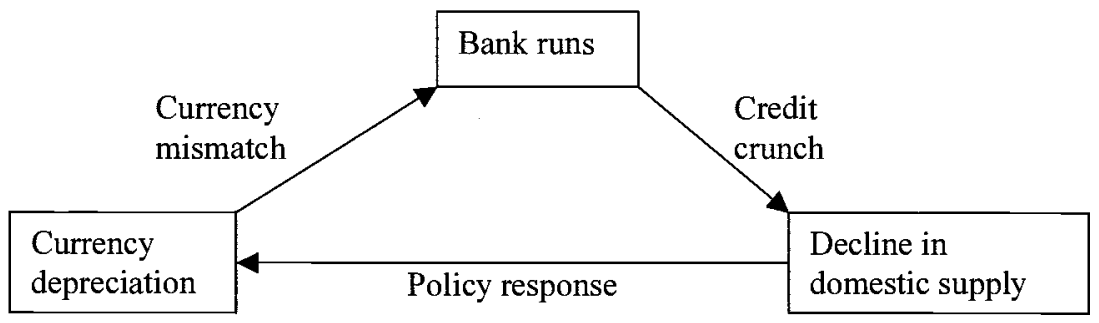

Fig. 4.5 The vicious spiral

undermine the currency. Devaluations, in turn, aggravate the existing banking-sector problems and create new ones. These adverse feedback mechanisms ... . can be amplified, as we have seen in several of the recent Asian crises, by banks' inadequate hedging of foreign-exchange risk."

We present a model (fig. 4.5) in which these negative feedback effects are linked together in the following vicious spiral: The currency depreciation triggers bank runs because of a currency mismatch in the balance sheets of domestic banks. Banking problems in turn depress domestic supply by inducing a credit crunch. Finally, the decline in domestic supply weakens the currency, as the domestic authorities attempt to boost output by a depreciation. This closes the circle.

In our model this vicious circle goes beyond making twin crises simply persistent or difficult to manage: it makes them self-fulfilling. We would like to emphasize, however, that we do not view this paper as a contribution to the debate on whether twin crises are self-fulfilling in the real world. The purpose of this paper is not to convince the reader that they were, in Asia or elsewhere. It is to study the feasibility of an international LOLR. It makes sense to look at this question in the context of a model with self-fulfilling bank runs, which is the problem that a LOLR is supposed to solve in theory.

\subsubsection{The Linkage from the Currency Depreciation to Bank Runs}

We consider a two-period model of an open emerging economy $(t=1,2)$. The agents are the domestic private banks, their depositors, and the domestic central bank. For the sake of brevity and couleur locale we call the domestic and foreign currencies peso and dollar respectively. We denote by $S_{t}$ the price of one peso in terms of dollars at time $t$. An increase in $S_{t}$ thus corresponds to an appreciation of the peso.

The peso/dollar exchange rate satisfies uncovered interest parity (UIP):

$$
S_{1}=\frac{1+i}{1+i^{*}} S_{2}^{e},
$$

where $S_{2}^{e}$ is the expected exchange rate, and $i$ and $i^{*}$ are respectively the peso and dollar riskless interest rates in period 1. 
Domestic banks have deposits and income streams denominated in dollars and pesos. The currency composition of banks' assets and liabilities is inherited from an earlier time, in which some banks found it optimal to borrow or lend in dollars or for some reason could not borrow in pesos. ${ }^{8}$ It does not seriously weaken our analysis to take the structure of banks' balance sheets as given, because we focus here on the policy measures at the time of the crisis, after the currency and maturity mismatches have built up. ${ }^{9} \mathrm{We}$ denote by $D(j)$ and $D^{*}(j)$ the quantities of peso and dollar deposits at bank $j$, and by $R_{t}(j)$ and $R_{t}^{*}(j)$ its peso-denominated and dollar-denominated income streams in period $t$.

Deposits are repayable on demand, and demand is served sequentially, as in Diamond and Dybvig's (1983) model of bank runs. Each bank has a continuum of atomistic depositors who decide at $t=1$ whether or not to withdraw their deposits. The withdrawing depositors are randomly allocated in a queue that determines the order in which they are served. The bank repays depositors by selling its assets for pesos or dollars in the market. If the bank does not have enough assets to repay all the withdrawing depositors in period 1 , the depositors at the end of the queue, and those who have not joined the queue, receive nothing. In the opposite case, the assets that remain in the possession of the bank at the end of period 1 are sold in period 2 to repay the remaining depositors - those who have not withdrawn in period 1. Deposits are interest bearing and yield the riskless interest rate corresponding to their currency of denomination. The holder of one dollar (peso) of deposit at time 1 is entitled to withdraw $1+i^{*}(1+i)$ dollars (pesos) at time 2.

We assume that bank assets are liquid in the sense that they can be sold costlessly on a perfectly competitive market at their present discounted value. This assumption is important insofar as it rules out bank runs à la Diamond and Dybvig, which are caused by the illiquidity of bank assets. ${ }^{10}$ Bank $j$ is solvent if, and only if, the present value of its income streams exceeds the value of its deposits, that is:

$$
D^{*}(j)+S_{1} D(j) \leq R_{1}^{*}(j)+\frac{R_{2}^{*}(j)}{1+i^{*}}+S_{1}\left[R_{1}(j)+\frac{R_{2}(j)}{1+i}\right]
$$

8. Chang and Velasco (2000) and Goldfajn and Valdes (1999) endogenize the maturity mismatch in open-economy versions of the Diamond-Dybvig model of bank runs. Burnside, Eichenbaum, and Rebelo (1999) and Schneider and Tornell (2000) endogenize the currency mismatch as the result of a government guarantee on foreign currency liabilities, whereas in Caballero and Krishnamurthy (2000) it is the result of domestic financial underdevelopment.

9. Of course it would be essential to endogenize the currency mismatch if we wanted to understand how policy measures can prevent its emergence ex ante (Jeanne, 2000c).

10. In theory, the benefit of banking intermediation should be linked to the illiquidity of bank assets. Assuming that bank assets are sold at a discount relative to their present value would not change the thrust of our results, and it is interesting to see that in fact we do not need this assumption. The role played by the illiquidity assumption in the bank run literature is played here by a state-conditional depreciation of the domestic currency. 
If this solvency condition is satisfied, the bank can repay all its depositors irrespective of the date at which they withdraw, and depositors have no (strict) incentives to withdraw early. If this condition is not satisfied, then all depositors run on the bank at period 1. Some depositors will have to take a loss, and each depositor minimizes the likelihood of being one of them by withdrawing his deposits early. Note that, by contrast with the DiamondDybvig model, the equilibrium is unique at the level of an individual bank. For a given balance sheet structure, the occurrence of a run is determined by interest and exchange rates, variables that are exogenous to the actions of the bank's depositors (the bank being very small).

In order to simplify the exposition we shall consider an extreme case of currency and maturity mismatch: all the deposits are denominated in dollars, and banks receive only one income stream, which is denominated in pesos and arrives in period 2. In terms of the variables of our model, this corresponds to the case in which $R_{1}^{*}, R_{2}^{*}, R_{1}$ and $D$ are equal to zero. The assumption that $R_{1}^{*}$ and $R_{2}^{*}$ are equal to zero does not restrict the generality of the analysis, and it is made simply to alleviate the algebra. The case in which $R_{1}$ and $D$ are different from zero is analyzed in the appendix. It has interesting implications for domestic monetary policy, which we choose not to discuss here because they are not essential to the core of our argument.

Using the interest parity condition in equation (1) to substitute $S_{1}$ and $i$ out of the solvency condition in equation (2), we find that bank $j$ is solvent if and only if

$$
D^{*}(j) \leq \frac{S_{2}^{e}}{1+i^{*}} R_{2}(j)
$$

In order to avoid the discontinuity associated with the use of integers, we assume that the set of banks is isomorphic to a continuum of mass 1 and that the banks' characteristics are continuously distributed. As equation (3) makes clear, the set of solvent banks shrinks if the expected peso exchange rate depreciates ( $S_{2}^{e}$ goes down). Consequently, the number of bank runs in period $1, n$, is a continuous and decreasing function of the expected exchange rate:

$$
n=N\left(S_{2}^{e}\right), \quad N^{\prime}<0
$$

An expected depreciation of the peso reduces the value of bank assets relative to their liabilities, drawing a larger number of banks into insolvency.

\subsubsection{The Reverse Linkage}

The linkage from bank runs to exchange rate expectations is in the spirit of the escape clause or second-generation approach to currency crises (Jeanne 2000a). It involves the endogenous policy response of the domestic authorities to the disruption in real activity induced by the bank runs. 
We assume that period-2 output is given by a standard Phillips curve augmented by a term reflecting the real disruption induced by runs on domestic banks in period 1. The law of one price applies, so that the Phillips curve can be written in terms of the exchange rate:

$$
Y_{2}=\bar{Y}-\alpha\left(S_{2}-S_{2}^{e}\right)-f(n), \quad f(0)=0, \quad f^{\prime}>0,
$$

$\bar{Y}$ is the natural level of output, and $n$ is the number of banks that are subject to runs in period 1. Bank runs reduce output by inducing a credit crunch: the banks that are subject to runs are no longer able to provide loans to borrowers with no easy access to other forms of finance. ${ }^{11}$ Function $f(\cdot)$ characterizes how the output loss in period 2 depends on the number of bank runs in period 1 . The output loss is increasing with the number of runs, presumably in a nonlinear way: for example, one could assume that a small number of bank runs has no effect on output but that widespread runs (the truly systemic banking crises) entail large output losses.

The domestic government minimizes the quadratic loss $L_{2}=\left(Y_{2}-\bar{Y}\right)^{2}+$ $\beta\left(S_{2}-\bar{S}\right)^{2}$. As in the classical Barro-Gordon setting, the exchange rate term captures an aversion to changes in the domestic price level (which are equivalent to changes in the exchange rate under the law of one price). We assume that the domestic government behaves in a discretionary way; that is, it minimizes its loss function in period 2, taking period 1 expectations as given. Using equation (5) to substitute out $Y_{2}$ in $L_{2}$, and minimizing over $S_{2}$, one finds that the period-2 exchange rate is a function of the number of bank runs and of the expected exchange rate:

$$
S_{2}=\frac{1}{\alpha^{2}+\beta}\left[\beta \bar{S}+\alpha^{2} S_{2}^{e}-\alpha f(n)\right]
$$

The expected exchange rate in period 2 is decreasing with the number of bank runs in period 1 , as the authorities attempt to mitigate the effect of the credit crunch on domestic output with a depreciation of the domestic currency.

\subsubsection{Multiple Equilibria}

We look at rational expectations Nash equilibria, in which each depositor decides whether or not to withdraw in period 1, taking the actions of the other depositors as given. Under rational expectations, the expected exchange rate and its realized level must coincide, because there is no uncertainty in the model. Replacing $S_{2}^{e}$ with $S_{2}$ in equations (4) and (6), we find

11. Disyatat (2000) presents a model of an open economy in which a depreciation tends to stimulate output because of a short-run Phillips curve but reduces the domestic banks' ability to lend. The credit crunch in his model comes from a reduction in banks' net worth, not from runs. 


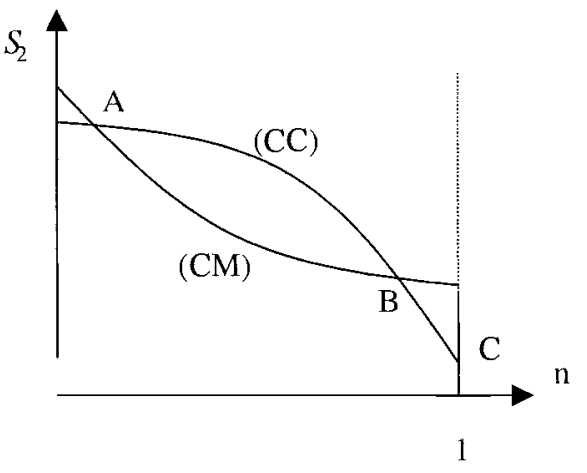

Fig. 4.6 Twin-crisis equilibria

that the number of bank runs and the second-period exchange rate are linked by two relationships:

$$
\begin{aligned}
n & =N\left(S_{2}\right), \quad(\mathrm{CM}) \\
\mathrm{S}_{2} & =\bar{S}-\frac{\alpha}{\beta} f(n), \quad(\mathrm{CC})
\end{aligned}
$$

The currency mismatch $(\mathrm{CM})$ relationship characterizes the linkage from the exchange rate to the number of bank runs. Its shape is determined by the currency mismatch in banks' balance sheets: in the absence of mismatch, the number of bank runs would not depend on the exchange rate. The credit crunch (CC) relationship characterizes the linkage from bank runs to the exchange rate. This link arises because the domestic authorities depreciate the currency in response to a credit crunch.

Figure 4.6 shows the $\mathrm{CC}$ and $\mathrm{CM}$ curves with the number of bank runs on the $\mathrm{x}$-axis and the exchange rate on the y-axis. Both curves are downwardsloping, so that the model generically gives rise to multiple equilibria. In the case represented in figure 4.6 there are two stable equilibria, corresponding to points $\mathrm{A}$ and $\mathrm{C}$. In the good equilibrium (point A) the currency is strong and only the "truly insolvent" banks are subject to runs. In the bad equilibrium (point C) the currency is expected to depreciate markedly, and all the banks are subject to runs. The equilibrium corresponding to point $\mathrm{B}$ is unstable. ${ }^{12}$

Note that, although bank runs may be self-fulfilling in this model, they never hit an "illiquid but solvent" bank. There is a perfect coincidence, in equilibrium, between runs and insolvency. In the bad equilibrium, the banks that are subject to runs are made insolvent by the pressure on the exchange rate. Some of these banks are "truly" or "virtually" solvent, in the sense that they would be solvent in the good equilibrium. However, it is im-

12. At point $B$, the bank runs caused by a slight fall in the expected exchange rate tend to depreciate the exchange rate even further, pushing the economy to point $\mathrm{C}$. 
portant to keep in mind that "true" solvency, understood in this sense, is an out-of-equilibrium concept.

\subsubsection{How Panics Depend on the Fundamentals}

The model makes several predictions about the conditions under which twin crises occur. First, there must be a significant currency mismatch in the balance sheets of domestic banks: the equilibrium is uniquely determined if banks' assets and liabilities are denominated in the same currency and, by continuity, if the two are sufficiently close. Second, the weight of the exchange rate (or price) objective in the authorities' loss function must be sufficiently small. If this weight, $\beta$, is large, the bad equilibrium disappears because bank runs are no longer expected to significantly depreciate the currency. ${ }^{13}$ Finally, self-fulfilling twin crises are more likely when the foreign interest rate, $i^{*}$, is high, because this increases the number of insolvent banks, other things being equal. ${ }^{14}$

It is not difficult to complicate the model slightly so as to make the multiplicity of equilibria contingent on other economic variables. For example, we could introduce a persistence effect in the Phillips curve, replacing equation (5) with

$$
Y_{2}=\bar{Y}+\rho\left(Y_{1}-\bar{Y}\right)-\alpha\left(S_{2}-S_{2}^{e}\right)-f(n)
$$

The second-period output now depends on its first-period level. Consequently, the second-period exchange rate will also depend on the firstperiod output $Y_{1}$, and twin crises can occur only if $Y_{1}$ is not too high. These results are broadly consistent with Kaminsky and Reinhart's (1999) observation that twin crises are preceded by recessions or below-normal economic growth and tend to occur when U.S. interest rates are high. The contingency of the multiplicity on output is not essential for our discussion, however, and we use the simpler model.

Whether the economy lands on one or the other of the equilibria may depend on a sunspot variable, which may or not be correlated with the underlying fundamentals. As one of us has argued elsewhere, the sunspot should not be interpreted literally, but rather as a "black box" for the littleunderstood phenomena involved in the selection of the equilibrium in the real world (Jeanne 2000a). ${ }^{15}$ We do not lose much from using this black box

13. In the limit case in which $\beta$ is infinite, the $\mathrm{CC}$ curve in figure 4.6 is horizontal, so that there is one unique equilibrium.

14. Raising $i^{*}$ increases the number of insolvent banks for a given exchange rate and shifts the $\mathrm{CM}$ locus to the right. Thus, this could shift the economy from a state in which the $\mathrm{CM}$ is everywhere below $\mathrm{CC}$ - so that there is one unique equilibrium with no bank run - to a state in which the $\mathrm{CM}$ and $\mathrm{CC}$ curves have multiple intersections.

15. Morris and Shin (1998) present a possible theory for the selection of the equilibrium. Their approach requires the number of equilibria to depend on the value of some exogenous hidden fundamental about which market participants receive private signals. It could be applied to our model by assuming, for example, that market participants do not know the true value of the domestic government's aversion to inflation, $\beta$. 
in this paper, because we look at policy measures that aim at removing the multiplicity of equilibria, not measures that aim at favoring the selection of the good equilibrium.

\subsection{The Limits of Monetary Policy}

This section presents the implications of the model for domestic monetary policy. We show that domestic monetary policy does not offer the right tools for dealing with twin crises. This point, which is of independent interest, is also important to justify the intervention of an international LOLR. If the domestic authorities could deal with twin crises by using monetary policy, there would be no need for an international LOLR. In addition, the model has interesting implications for exchange rate regimes, which we briefly discuss in section 4.4.2.

\subsubsection{The Irrelevance of Interest Rates}

The most immediate question that policy makers have to solve in the heat of crises is macroeconomic: what to do with the interest rate? The debates spurred by the IMF's policy recommendations in the Asian crisis have seen the opposition between two views: the view that the interest rate should be raised, at least for a while, in order to defend the currency, and the view that it should be kept at a low level to spare the domestic economy. The advocates of the latter view have pointed out that a policy of high interest rate may be self-destructive to the extent that it aggravates the real problems in the economy, in particular in the banking sector (Furman and Stiglitz 1998). The opposite side has emphasized that letting the currency depreciate is not a viable alternative when there is a currency mismatch in the balance sheet of banks or firms. Our model is consistent with at least one part of each view: monetary policy simply does not offer the right tools to deal with twin crises.

In our model, low or high interest rates are equally ineffective against twin crises. In order to establish this point, it is sufficient to recall that the domestic interest rate, $i$, was not in the list of variables that determine the set of equilibria. Hence, if the economy is vulnerable to a self-fulfilling twin crisis, there is nothing that the domestic authorities can do about it by manipulating the domestic interest rate.

One may dig out the economic intuition behind this result by going back to the condition for bank solvency, equation (3). The solvency of banks is determined by one variable: the time-1 dollar price of time- 2 pesos, $S_{2}^{e} /(1+$ $\left.i^{*}\right)$. Under UIP, his price can be decomposed as the product of two terms, the time-1 peso price of a time-2 peso, and the time-1 exchange rate:

$$
P^{*}=\frac{1}{1+i} \cdot \frac{(1+i) S_{2}^{e}}{1+i^{*}}
$$


The first term is decreasing with $i$, while the second term is increasing with $i$. Increasing $i$, thus, has two opposite effects, which capture the two sides of the debate mentioned above. On the one hand, raising $i$ undermines banks' solvency by depressing the peso price of long-term peso assets. On the other hand, this enhances banks' solvency by appreciating the domestic currency. The first effect arises because of the maturity mismatch in the balance sheet of banks, and the second effect because of the currency mismatch. On balance, the two effects cancel each other out, so that the level of the interest rate is irrelevant.

The two effects exactly cancel each other out because of the particular assumptions we have made on the currency and maturity structure of banks' balance sheets - that bank deposits are denominated in dollars, and that their receipts are given in period-2 pesos. The robustness of our results to more general assumptions is explored in the appendix. We show there that the solvency of banks is no longer independent of the level of the interest rate, so that a policy of high interest rates may or not dominate a policy of low interest rates. A policy of high interest rates tends to become more desirable when the maturity mismatch between the peso-denominated assets and liabilities of banks is less pronounced.

This extension, however, does not invalidate our main conclusion. If the weight of price stability in domestic objectives is too low and the currency mismatch is severe, self-fulfilling twin crises may exist, and if they do, monetary policy is powerless in preventing them. This is because the scope of monetary policy in preserving banks' solvency, although no longer completely empty, remains limited and contingent on exchange rate expectations.

\subsubsection{Implications for Exchange Rate Regimes}

The recent major twin crises were all associated with fixed but adjustable currency pegs, whence the natural conclusion that in order to be viable, exchange rate regimes have to be either more flexible or more fixed. The exchange rate alternative, for emerging economies, is increasingly defined as a choice between corner solutions - between exchange rate flexibility and very hard pegs (Eichengreen 1999; Rubin 1999).

In the debate between the extremes, a classical argument in favor of flexibility is that it gives monetary policy more scope to respond to shocks, especially in times of crisis. However, the apparent margin of maneuver offered by a flexible exchange rate is largely illusory in our model. ${ }^{16}$ The reason is that the threat is not a currency crisis (a run on the central bank's foreign exchange reserves) but a bank crisis (a run on dollar deposits in banks). The occurrence of bank runs is determined by the dollar price of future pesos. Whether a given change in this price is achieved by changing the inter-

16. It is completely illusory under the assumption that $D$ and $R_{1}$ are equal to zero. It is not completely illusory, but remains limited, in the more general case (see appendix). 
est rate or the exchange rate is irrelevant for financial stability. Although it is true that a floating regime allows the monetary authorities to set a lower interest rate in the face of speculative pressure, the resulting depreciation hurts domestic banks no less than high interest rates.

Indeed, if the model has an implication for exchange rate regimes, it is rather to suggest the optimality of very hard pegs, or dollarization. If the defense of the fixed peg is delegated to a conservative central banker putting a very high weight $\beta$ on exchange rate stability, the bad equilibrium disappears. If, more generally, the domestic authorities find a way to make a credible commitment to exchange rate stability, the vicious spiral that underpins twin crises is broken, because bank runs no longer feed devaluation expectations. Dollarization can be interpreted as the limit case in which $\beta$ is infinite, so that there is no exchange rate uncertainty. Twin crises obviously cannot arise in countries that have dollarized, because then there is no currency mismatch in the balance sheets of banks: both banks' assets and liabilities are denominated in dollars.

This might lead us to conclude in favor of very hard pegs over exchange rate flexibility. However, this conclusion should be qualified by two important caveats. First, the currency mismatch that is taken as exogenous in the model could in fact be endogenous to the exchange rate regime. It is often argued that regimes with fixed but adjustable exchanges are conducive to currency mismatches because domestic borrowers tend to underestimate the risk of a devaluation (Lindgren et al. 1999). The model does not capture one possible benefit of exchange rate flexibility - in fact, the only possible benefit, under our assumptions - which is that it prevents the emergence of currency mismatches.

The second caveat is that although hard pegs or dollarization remove the twin crises resulting from currency mismatches in the banking sector-the crises that we focus on in this paper-they do not remove banking panics à la Diamond and Dybvig, which result instead from the illiquidity of bank assets. If bank runs à la Diamond and Dybvig are possible, a group of countries linked by a system of hard pegs or a common currency may still need an international lending-of-last-resort arrangement. This is why the reluctance of the U.S. Federal Reserve to assume the role of LOLR abroad may be viewed as a valid argument against dollarization in Latin American countries. This is also why the euro area may need an international LOLR. ${ }^{17}$

\subsection{The International Lender of Last Resort}

Our model seems to provide an ideal setting for the intervention of an international LOLR. Domestic banks are vulnerable to self-fulfilling runs be-

17. See Prati and Schinasi (2000) for a discussion on lending-in-last-resort arrangements in the euro area. 
cause the country as a whole lacks international liquidity. Perhaps the bad equilibrium could be removed by an international LOLR standing ready to provide the missing international liquidity to the country in the event of a twin crisis. ${ }^{18}$

Let us rephrase the question in the context of the model, with some new notations. Let $D^{*}=\int D^{*}(j) d j$ be the aggregate level of dollar deposits in the domestic banking sector, $X^{*}$ the level of foreign exchange reserves at the domestic central bank, and $L^{*}$ the dollar endowment of the international LOLR. The international LOLR could promise to augment the domestic foreign exchange reserves by lending up to $L^{*}$, in which case the domestic central bank's access to international liquidity is limited to $X^{*}+L^{*}$ in a crisis. Alternatively, the international LOLR could use its resources directly, without the mediation of the domestic authorities. The question, in both cases, is how large $L^{*}$ should be to remove the bad equilibrium.

Throughout the analysis we require the international LOLR to remove the bad equilibrium without affecting the good one. In the good equilibrium, some banks - the "truly insolvent" ones - are subject to runs (see figure 4.6). Rescuing these banks, however, is a bailout, not a lending-in-lastresort operation. Bailing out insolvent banks has costs in terms of moral hazard ex ante that, although they are not explicitly modeled in our framework, may be important in the real world. As a matter of definition, it is not the purpose of a LOLR to bail out insolvent institutions.

\subsubsection{A Global Central Bank}

Goodfriend and King (1988) argue, in a domestic context, that the LOLR should inject liquidity into the market by open market operations. ${ }^{19}$ Lending in last resort, in other words, should involve the same operations as monetary policy in normal times, although possibly to a much larger scale. According to this view, lending-in-last-resort policies in which the authorities attempt to bypass the market and target liquidity directly at selected institutions - for example, by lending to them at the discount window-is a vestige of a time when financial markets did not have the depth and efficiency that they have achieved today.

This view is based on the premise that market forces will allocate the liquidity better than the authorities. Market participants have more information than the authorities on the situations of individual banks and are not subject to the temptation of bailing out insolvent banks under political

18. The lending-in-last-resort arrangement could involve a pool of private banks. However, there are reasons (outside of the model) that the provision of liquidity by public institutions may be more effective. In particular, it may be difficult for private banks to commit not to hedge their risk by market operations that drain international liquidity from the country in the event of a crisis. A comparison between the various possible types of lending-in-last-resort arrangement is outside the scope of this paper.

19. The origin of this view is sometimes traced back to Thornton ([1802] 1978) and Humphrey (1975)—see Fischer (2000). 
pressure. Market forces, thus, will ensure that the liquidity is allocated to the "truly solvent" banks. Goodfriend and King call this policy "lendingin-last resort as an input into monetary policy," as opposed to "lending-inlast resort as an input into banking policy."

What should the international LOLRs do, according to this approach? In the closed-economy context, considered by Goodfriend and King, the LOLR injects liquidity into the market by open market operations, that is, by buying bonds in exchange of domestic money. The open-economy ana$\log$ is an injection of international liquidity, that is, in our model, dollars. The international LOLR provides international liquidity to the market by buying peso-denominated bonds in exchange of dollars, that is, by a sterilized foreign exchange intervention. If markets are perfectly integrated internationally, it does not matter whether the foreign exchange intervention is realized by the international LOLR or by the domestic central bank, or in which point of the globe the intervention is implemented.

In our model, this approach is completely ineffective in removing the bad equilibrium. Because of UIP, sterilized foreign exchange interventions have no impact on the interest rate, the exchange rate, or the depositors' actions. In particular, every billion dollars that is injected in the market by the domestic central bank simply goes out of the country in capital outflows. Domestic foreign exchange interventions, in other words, are immediately sucked out of the country in capital outflows instead of going to the agents that need foreign liquidity the most, the domestic banks that are subject to runs.

Our model suggests that if lending in last resort is an input into monetary policy, then it should be carried out by the center's monetary authorities (in the present case in which foreign assets are dollar denominated, the U.S. Federal Reserve). There are at least two ways in which this statement can be understood. First, as we already saw, lowering the foreign interest rate, $i^{*}$, may remove the bad equilibrium. Second, the Federal Reserve could successfully peg the dollar price of future pesos at the good equilibrium level, $P_{A}^{*}$. If the dollar price of peso bonds is equal to $P_{A}^{*}$, the number of bank runs is equal to its good equilibrium level, $n_{A}$, so that the set of equilibria is reduced to the good equilibrium.

In our model, the dollar price of future pesos cannot be pegged at a level that is inconsistent with UIP. In order to peg this price, the international LOLR would have to inject dollars in the market until the point when market participants can no longer increase their short positions in peso (because of credit constraints or for other reasons) so that UIP ceases to apply. This would require an immense liquidity injection at the global scale, which can be implemented, in practice, only by the issuer of the center currency. Making international lending in last resort an input in monetary policy thus vindicates Capie's (1998) claim that the international LOLR must be the is- 
suer of the international currency: a global central bank, or the U.S. Federal Reserve if the international currency is the dollar.

These results stem, in part, from our assumption that financial markets are perfectly integrated internationally. If financial markets were segmented, international liquidity might have a better chance to reach domestic banks if it were injected in the domestic financial market. Uncovered interest parity also plays a role. In the presence of portfolio effects, the domestic currency could in principle be strengthened by sterilized foreign exchange interventions.

Market segmentation is to some extent a policy variable: the domestic authorities can enhance the segmentation of financial markets by introducing capital controls. Although the analysis of capital controls is outside the scope of this paper, it would be interesting to study whether, and how, capital controls can remove self-fulfilling twin crises in our model. Although capital controls may prevent depositors from taking their dollar deposits out of the country, they will not prevent them from running on the domestic banks that they view as insolvent. The solvency of banks in turn results from the expected exchange rate. Hence, capital controls can remove twin crises only to the extent that this gives the authorities more scope in influencing exchange rate expectations. This could be the case, for example, if the controls introduce a wedge in the interest parity condition.

Let us conclude this section with a metaphor-a hydraulic one, as is often the case in monetary economics. Imagine a small harbor in Brittany: the tide is low and boats are resting on the bottom of the sea, inside the harbor. Lending in last resort by injecting liquidity into the market is like trying to lift the boats by pouring water into the ocean. To be successful, this approach requires an immense reserve of water (an ability to melt the North Pole, say). Imagine now that the harbor is separated from the ocean by a wall and a door. Once the door is closed (capital controls are introduced), one obviously needs to pour much less liquidity inside the harbor to lift the boats.

\subsubsection{An "International Banking Fund"}

We now consider some arrangements in which the international LOLR can operate as a limited fund. The main difference from the previous section is that the resources of the international LOLR are channeled to the banks on a case-by-case basis instead of being simply "thrown at the market," in Goodfriend and King's terminology, the international LOLR provides an input into banking policy instead of monetary policy. We consider two arrangements. In the first one, the resources of the international LOLR are used to finance discount-window lending by the domestic central bank. In the second one, the international LOLR backs limited guarantees on dollar deposits at domestic banks. 
In the discount-window lending policy, the domestic banks that are subject to runs queue at the discount window of the domestic central bank. ${ }^{20}$ The latter selects the "truly solvent" banks and lends them all the dollars they need to repay their depositors. The remaining banks receive nothing and collapse. It is important to keep in mind that the solvency of banks is contingent on the equilibrium and that we define "true" solvency with reference to the good equilibrium. In other terms, in the bad equilibrium the authorities assess the solvency of banks as if the economy were in the good equilibrium. In a banking panic, "true" solvency is an out-of-equilibrium attribute, not an observable, objective reality.

That banks' solvency should be assessed with reference to hypothetical market conditions is consistent with some interpretations of the classical doctrine of lending in last resort. This is, for example, the way Fischer (1999) interprets Bagehot's rule that the LOLR should lend "on any collateral that is marketable in the ordinary course of business when there is no panic." The requirement that lending should be made on the basis of the value of collateral in normal times can be interpreted as taking the good equilibrium as the benchmark to assess the solvency of banks. In terms of our model, the authorities must assess the value of banks' collateral on the basis of the price that prevails in the good equilibrium, $P_{A}^{*}$. In the bad equilibrium, $P_{A}^{*}$ is a shadow price that is larger than the observed market price, $P_{C}^{*}$.

It is easy to see that this arrangement reduces the set of equilibria to the good equilibrium. The international LOLR's intervention breaks the vicious circle depicted in figure 4.5 by preventing bank runs from resulting in an excessive depreciation of the exchange rate. It ensures that the solvent banks remain in operation and that their balance sheets do not shrink in response to runs. For these banks, the only effect of the run is a substitution of creditors: private depositors are replaced by the central bank. As a result, there is no credit crunch in the "truly solvent" part of the banking sector, and the pressure on the exchange rate is reduced accordingly.

The argument can be presented more formally - in terms of the equations of the model — as follows. Let $n_{A}$ denote the number of insolvent banks in the good equilibrium. With discount-window lending, runs on the (truly) solvent banks no longer contribute to the credit crunch, so that in the Phillips curve of equation (5) variable $n$ must be replaced by $\min \left(n, n_{A}\right)$, the number of insolvent banks that are subject to runs. The equation for the linkage from bank runs to the exchange rate then becomes

$$
S_{2}=\bar{S}-\frac{\alpha}{\beta} f\left[\min \left(n, n_{A}\right)\right] \quad\left(\mathrm{CC}^{\prime}\right)
$$

20. This is the way lending in last resort is modeled in Chang and Velasco (2000) and Goldfajn and Valdés (1999). 


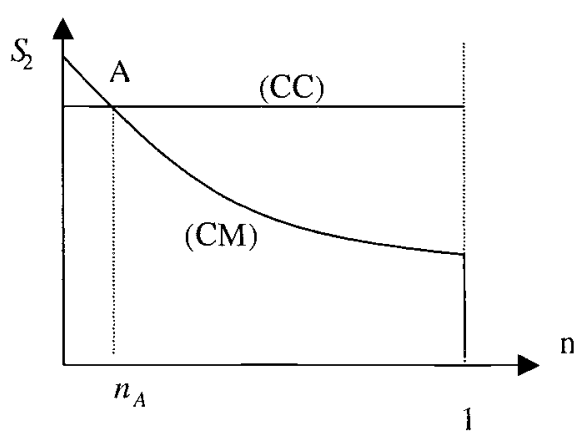

Fig. 4.7 Discount-window lending

In figure 4.6 the locus (CC) becomes horizontal to the right of point $\mathrm{A}$, implying that the set of equilibria is reduced to the good equilibrium (see figure 4.7).

The case in which the international LOLR backs a domestic guarantee on the dollar deposits can be analyzed along similar lines, although there is an interesting difference in the economic mechanism involved. The government announces that it guarantees deposits at (truly) solvent banks (again, true solvency is assessed with reference to the good equilibrium). This breaks the vicious circle depicted in figure 4.5 by suppressing the linkage from the currency depreciation to bank runs. The depositors, once insured, no longer have (strict) incentives to run against the (truly) solvent banks. The expectation of a depreciation is no longer self-fulfilling because it does not provoke a banking collapse.

In terms of the equations of the model, the guarantee affects the relationship between the expected exchange rate and the number of bank runs, equation (4). Developments in the foreign exchange market no longer affect the (truly) solvent banks, so that equation (4) is replaced by $n=\min \left[n_{A}\right.$, $\left.N\left(S_{2}^{e}\right)\right]$. The equation for locus $(\mathrm{CM})$ becomes

$$
n=\min \left[n_{A}, N\left(S_{2}\right)\right] \quad\left(\mathrm{CM}^{\prime}\right)
$$

In figure 4.6 the locus $(\mathrm{CM})$ becomes vertical in point $\mathrm{A}$, so that again the good equilibrium is the only one (see fig. 4.8). In order for these arrangements to be operational, the resources of the international LOLR do not need to be larger than the liquidity gap in the domestic banking sector, $D^{*}$ $-X^{*}$. Indeed, its resources could even be smaller, because the liabilities of the truly insolvent banks do not have to be covered in the event of a crisis. This does not seem unrealistically large. As documented in section 4.2, the IMF-supported rescue packages were of the same order of magnitude as the liquidity gap in the Asian countries that were most affected by the crisis. 


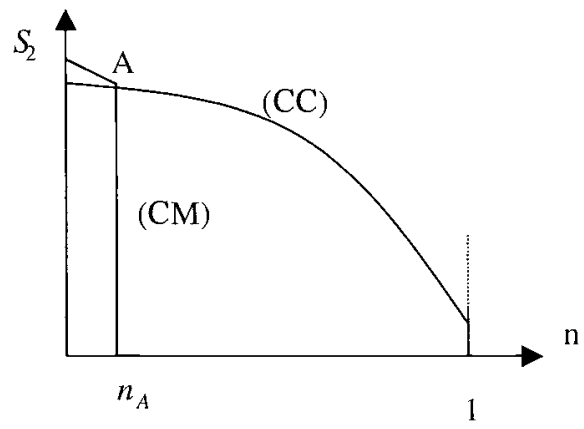

Fig. 4.8 Guarantee on dollar deposits

In sum, we find that an international LOLR backing domestic safety nets needs much less resources than an international LOLR injecting liquidity in the market. It can operate as a limited "International Banking Fund" and would not necessarily need to be considerably larger than existing international financial institutions. This conclusion, however, ignores one important aspect of the problem, to which we now turn: agency problems between the international LOLR and the domestic authorities.

\subsubsection{International Agency Problems}

One question that we have not addressed so far is the articulation between the international LOLR and the domestic authorities. To what extent should the international LOLR rely on the domestic authorities to funnel the liquidity toward domestic banks? So far, this question has not come up because we implicitly assumed that the international LOLR and the domestic authorities shared the same objectives. However, the involvement of two different authorities in the international lending-in-last-resort arrangement might give rise to agency problems (Tirole 2001). We discuss in this section how agency problems might arise in our framework, as well as the measures to mitigate them.

An agency problem would arise if the domestic authorities thought that the cost of bailing out the truly insolvent banks could somehow be transferred to the international community. The domestic authorities would then be tempted to use the lending-in-last-resort resources in order to bail out the domestic banks that are insolvent in the good equilibrium, at the expense of the foreign taxpayers. As argued by Jeanne and Zettelmeyer (2001), an agency problem could arise even if the fiscal cost of the bailout is borne by the domestic taxpayer. In this case, the problem is that the domestic authorities use the bridge loans from the international community to be overly generous with the domestic special interests that benefit from the bailout, at the expense of the domestic taxpayers.

Agency problems could arise at several levels. First, the international 
LOLR might be unable to ensure that its resources were not misused by the domestic authorities (to bail out insolvent banks). Second, even if the international LOLR had full control of the way its resources were used - which would be the case, for example, if it lent directly to domestic banks - it might not have all the information that is required to use these resources appropriately. Ideally, the international LOLR should be able to assess the "true" solvency of banks in a crisis. This is informationally very demanding: it requires a precise knowledge of the various feedbacks between the banking system, the productive sector, and the foreign exchange market, as well as the structure of banks' balance sheets. ${ }^{21}$ In a world where banking supervisory policies are determined at the national level, most of the relevant knowledge is the private information of the domestic authorities, and they would have little incentive to reveal it truthfully to the international LOLR.

There are different ways to deal with this agency problem, but they all seem to require a significant involvement of the international LOLR in banking supervision and safety nets. The international LOLR would have to be associated with the lending-in-last-resort decisions at the time of the crisis and should be able to form an independent judgment on the true solvency of banks in a banking crisis. This supposes some access to the information of the banking supervisors and some assurance that this information is reliable. Consequently, the international LOLR would probably have to take an active role in monitoring domestic banking systems or cooperate closely with an international agency in charge of international supervision..$^{22}$

How realistic is this involvement of the international LOLR in the supervision of domestic banking sectors? In spite of efforts to promote international standards, the operation of financial safety nets and financial oversight policies remains - and will remain for the foreseeable futuresquarely within the bounds of national sovereignty (Eichengreen 1999). Nations remain jealous of their prerogatives in the regulation and supervision of their banking sectors, and there seems to be little political appetite for a globally integrated system with the IMF, the BIS, or any new institution at its center. The domestic resistance to the integration of banking supervision in the euro area - which is so closely integrated in other respects - gives an idea of the difficulties that would arise at the global level. Ultimately, it is not clear that a globally integrated system of banking supervision is more realistic than a global central bank.

21. As we saw in the previous section, banks' solvency must be assessed on the basis of an appropriate shadow price for the collateral. Computing the shadow price is challenging. In general, there is no reason to presume that the appropriate shadow price is close to the precrisis level. In a world where crises are associated with the arrival of news about the fundamentals, the appropriate shadow price should be revised in light of the new information revealed by (or causing) the crisis.

22. The IMF has recently enhanced its monitoring of domestic banking and financial systems with, for example, the development of its Financial Sector Assessment Programs (FSAP); see IMF (2001). 


\subsection{Concluding Comments}

The main result of this paper should be to instill a solid degree of skepticism regarding the feasibility of an international LOLR without sweeping institutional reforms. If the international LOLR uses its resources as an input into monetary policy, the model presented here vindicates those who claim that it must stand ready to provide virtually unbounded amounts of currency. Central banks satisfy this condition, not any existing international financial institution. The alternative is an "International Banking Fund" that is directly involved in the supervision of the domestic banking systems that it might be called upon to rescue - an institutional arrangement that would also require significant reforms in the international financial architecture.

An interesting by-product of the paper is an interpretation of the tradeoff that central banks often face at the time of currency crises. A vigorous interest rate defense weakens the banking system. If banks are fragile, central banks risk triggering a bank run and may end up with both a currency crash and a bank collapse. On the other hand, letting the currency go is not a solution either, because this also weakens the banking system by decreasing the dollar value of its assets. This dilemma explains part of the debate that has arisen after the Asian crisis between those who favored a vigorous interest rate defense and those who called for a sharp decline in interest rates.

The model presented has a number of microeconomic loose ends. The special role of banks in financial intermediation, which is invoked to justify the credit crunch term in the Phillips curve, is not explicitly modeled. The balance sheet effects, which are so important in triggering bank runs in period 1, are neglected in period 2. Fixing these loose ends will probably lower the insight-to-algebra ratio, a price that seems to us worth paying now that we have taken a panoramic shot of the range of policy issues on which the model sheds light.

The model also glosses over several important moral hazard issues. This includes the role of a fixed exchange rate as an implicit guarantee on foreign borrowing and the effect of a LOLR on risk taking. Finally, it should be noted that if regulation prohibiting open currency position by banks is effective, none of our results obtain. Then, however, we would need to take into account the fact that firms rarely face such a regulation. If the corporate sector becomes insolvent, as banks do in our model, and precipitates bank failures, most of our results stand. However, there are interesting differences in the effectiveness of financial safety nets, which would be interesting to explore further. It is not so clear that the provision of liquidity to the banking sector, or government guarantees on banks' liabilities, would remove the bad equilibrium if the currency mismatch is in the corporate sector. 


\section{Appendix A}

\section{Data Sources}

Foreign exchange reserves: International Financial Statistics, line 1d. Short-term debt to Bank of International Settlements (BIS) reporting banks: BIS.

Foreign liabilities of deposit money banks: International Financial Statistics, line $26 \mathrm{c}$.

Liquidity support to financial institutions: author's computations based on Lindgren et al. (1999, table 3).

IMF-supported packages (disbursements): author's computations based on different sources; this variable includes the loans by the IMF, other multilaterals, and governments; it reflects the actual disbursements, which were lower than the initial commitments.

Bank closures: Lindgren et al. (1999, table 7).

Total assets owned by banks: Lindgren et al. (1999, box 3).

GDP (US\$billions): International Financial Statistics, line 99b (Gross Domestic Product, national currency) divided by line rf (exchange rate).

\section{Appendix B}

This appendix solves for the equilibria in the general case in which banks have peso- and dollar-denominated deposits and income streams. The quantities of peso and dollar deposits at bank $j$ are denoted by $D(j)$ and $D^{*}(j)$. Bank $j$ 's peso-denominated and dollar-denominated income streams in period $t$ are denoted by $R_{t}(j)$ and $R_{t}^{*}(j)$.

Using UIP in equation (1) to substitute $S_{1}$ out of equation (2), the condition for bank $j$ 's solvency becomes

$$
\text { (A1) } \begin{aligned}
& D^{*}(j)-\left[R_{1}^{*}(j)+\frac{R_{2}^{*}(j)}{1+i^{*}}\right] \\
&<\frac{S_{2}^{e}}{1+i^{*}}\left\{\left[R_{1}(j)-D(j)\right](1+i)+R_{2}(j)\right\}
\end{aligned}
$$

The impact of the interest level on bank $j$ 's solvency depends on the sign of $R_{1}(j)-D(j)$, which reflects the maturity mismatch between assets and liabilities denominated in domestic currency. If $R_{1}(j)-D(j)<0$, that is, if the bank has more short-term debt than liquid assets in domestic currency, then raising the interest rate undermines the bank's solvency. On the other hand, if $R_{1}(j)-D(j)>0$, raising the interest rate enhances the bank's solvency. 
In aggregate, raising the interest rate increases (reduces) the number of insolvent banks if $R_{1}(j)-D(j)<0\left[R_{1}(j)-D(j)>0\right]$ for all banks. If the sign of $R_{1}(j)-D(j)$ differs across banks, then the impact of the interest rate on the number of insolvent banks is ambiguous. We denote by $I\left(S_{2}^{e}\right)$ the interest level that minimizes the number of insolvent banks when the expected exchange rate is $S_{2}^{e}$, and by $N\left(S_{2}^{e}\right)$ the corresponding number of insolvent banks.

How does the minimum number of insolvent banks, $N\left(S_{2}^{e}\right)$, vary with the expected exchange rate? This question is easy to answer if we assume that all the banks are short in dollars, that is, if the left-hand side of equation (A1) is positive. Then the set of solvent banks shrinks for any level of the interest rate when $S_{2}^{e}$ decreases, implying that the minimum number of insolvent banks, $N\left(S_{2}^{e}\right)$, is a decreasing function of $S_{2}^{e}$.

We define the rules of the game between the domestic central bank and the depositors as follows. First, the central bank announces how it will adjust the interest rate to the economic conditions, that is, its policy reaction function $i\left(S_{2}^{e}\right)$. Then depositors play the same Nash game as before, taking the central bank policy reaction function as given. Depositors still maximize their expected consumption, and the central bank minimizes its expected loss $L_{2}^{e}$.

Because the central bank's expected loss is increasing in the number of bank runs, it optimally announces the policy rule that minimizes the number of runs, $I\left(S_{2}^{e}\right)$. Given this policy rule, the equilibrium number of runs is a decreasing function of the expected exchange rate, like before:

$$
n=N\left(S_{2}^{e}\right), \quad N^{\prime}<0 .
$$

This equation is the same as equation (4) in the text, and the characterization of the equilibria remains the same.

\section{References}

Aghion, Philippe, Philippe Bacchetta, and Abhijit Banerjee. 2000. Currency crises and monetary policy in an economy with credit constraints. Harvard University, Department of Economics. Mimeograph.

Bacchetta, Philippe. 2000. Monetary policy with foreign currency debt. Bank of Switzerland, Study Center Gerzensee. Mimeograph.

Bordo, Michael. 1990. The lender of last resort: Alternative views and historical experience. Federal Reserve Bank of Richmond Economic Review 76 (1): 18-29.

Burnside, Craig, Martin Eichenbaum, and Sergio Rebelo. 1999. Hedging and financial fragility in fixed exchange rate regimes. Northwestern University, Kellogg Graduate School of Management. Mimeograph.

Caballero, Ricardo J., and Arvind Krishnamurthy. 2000. Dollarization of liabilities: Underinsurance and domestic financial underdevelopment. Massachusetts Institute of Technology, Department of Economics. Mimeograph. 
Calomiris, Charles W. 1998. The IMF's imprudent role as lender of last resort. Cato Journal 17:275-95.

Capie, Forrest. 1998. Can there be an international lender-of-last-resort? International Finance 1:311-25.

Céspedes, L. F., Roberto Chang, and Andrés Velasco. 2000. Balance sheets and exchange rates. NBER Working Paper no. 7840. Cambridge, Mass.: National Bureau of Economic Research.

Chang, Roberto, and Andres Velasco. 2000. Liquidity crises in emerging markets: Theory and policy. In NBER macroeconomics annual 1999, ed. Ben S. Bernanke and Julio Rotemberg, 11-58. Cambridge: MIT Press.

Christiano, Lawrence J., Christopher Gust, and Jorge Roldos. 2000. Monetary policy in a financial crisis. Washington, D.C.: International Monetary Fund. Mimeograph.

Diamond, Douglas, and P. Dybvig. 1983. Bank runs, deposit insurance, and liquidity. Journal of Political Economy 91:401-19.

Ding, Wei, Ilker Domaç, and Giovanni Ferri. 1998. Is there a credit crunch in East Asia? World Bank Policy Research Working Paper no. 1959. Washington, D.C.: World Bank.

Disyatat, Piti. 2000. Currency crises and the real economy: The role of banks. Princeton University, Department of Economics. Mimeograph.

Eichengreen, Barry. 1999. Toward a new financial architecture. Washington, D.C.: Institute for International Economics.

Fischer, Stanley. 1999. On the need for an international lender of last resort. Journal of Economic Perspectives 13:85-104.

-2000. On the need for an international lender of last resort. Essays in International Economics, no. 220. Princeton, N.J.: Princeton University Press.

Fratianni, Michele, and John Pattison. 2001. International lender of last resort: A concept in search of a meaning. Indiana University, Kelley School of Business. Mimeograph.

Freixas, Xavier, and Jean-Charles Rochet. 1997. Microeconomics of banking. Cambridge: MIT Press.

Furman, Jason, and Joseph Stiglitz. 1998. Economic crises: Evidence and insights from East Asia. Brookings Papers on Economic Activity, Issue no. 2:1-114. Washington, D.C.: Brookings Institution.

Garten, Jeffrey. 1998. In this economic chaos, a global central bank can help. International Herald Tribune, 25 September.

Gertler, Mark, Simon Gilchrist, and Fabio M. Natalucci. 2000. External constraints on monetary policy and the financial accelerator. New York University, Department of Economics. Mimeograph.

Ghosh, Swati R., and Atish R. Ghosh. 1999. East Asia in the aftermath: Was there a crunch? IMF Working Paper no. WP/99/54. Washington, D.C.: International Monetary Fund.

Giannini, Curzio. 2002. Pitfalls in international crisis lending. In Financial crises, contagion, and the lender of last resort: A reader, ed. Charles Goodhart and Gerhard Illing, 511-46. Oxford, England: Oxford University Press.

Goldfajn, Ilan, and Rodrigo Valdes. 1999. Liquidity crises and the international financial architecture. Pontificia Universidade Catolica do Rio de Janeiro. Department of Economics. Mimeograph.

Goodfriend, Marvin, and Robert King. 1988. Financial deregulation, monetary policy, and central banking. In Restructuring banking and financial services in America, ed. W. Haraf and R. M. Kushmeider, 216-53. Lanham, Maryland: American Enterprise Institute and UPA. 
Goodhart, Charles, and Haizhou Huang. 2000. A simple model of an international lender of last resort. IMF Working Paper no. WP/00/75. Washington, D.C.: International Monetary Fund.

Humphrey, Thomas. 1975. The classical concept of the lender of last resort. Federal Reserve Bank of Richmond Economic Review 61:2-9.

International Financial Institution Advisory Commission (IFIAC). 2000. Report of the International Financial Institution Advisory Commission, Allan H. Meltzer, chairman, (Meltzer report). Washington, D.C.: U.S. Congress.

International Monetary Fund (IMF). 2001. Report of the managing director to the International Monetary and Financial Committee on the IMF in the process of change. Available at [http://www.imf.org/external/np/omd/2001/report.htm].

Jeanne, Olivier. 2000a. Currency crises: A perspective on recent theoretical developments. Special Papers in International Economics no. 20. Princeton University, Department of Economics.

- 2000b. Debt maturity and the global financial architecture. Center for Economic Policy Research Discussion Paper no. 2520. London: Center for Economic Policy Research.

- 2000c. Foreign currency debt and the global financial architecture. European Economic Review 44:719-27.

Jeanne, Olivier, and Jeromin Zettelmeyer. 2001. International bail-outs, moral hazard, and conditionality. Economic Policy 33 (October): 407-32.

Kaminsky, Graciela, and Carmen Reinhart. 1999. The twin crises: The causes of banking and balance-of-payments problems. American Economic Review 89:473500 .

Kumar, Mohan, Paul Masson, and Marcus Miller. 2000. Global financial crises: Institutions and incentives. IMF Working Paper no. WP/00/105. Washington, D.C.: International Monetary Fund.

Lindgren, Carl-Johan, Tomas J. T. Baliño, Charles Enoch, Anne-Marie Gulde, Marc Quintyn, and Leslie Teo. 1999. Financial sector crisis and restructuring: Lessons from Asia. IMF Occasional Paper no. 188. Washington, D.C.: International Monetary Fund.

Morris, Stephen, and Hyun Song Shin. 1998. Unique equilibrium in a model of selffulfilling currency attacks. American Economic Review 88:587-97.

Prati, Alessandro, and Gary Schinasi. 2000. Will the European Central Bank be the lender of last resort in EMU? In The euro: A challenge and opportunity for financial markets, ed. M. Artis, A. Weber, and E. Hennessy, 227-56. New York: Routledge.

Rogoff, Kenneth. 1999. International institutions for reducing global financial instability. Journal of Economic Perspectives 13:21-42.

Rubin, Robert E. 1999. Testimony on global financial architecture before the House Committee on Banking and Financial Institutions. 20 May. Available at [http:// www.ustreas.gov/press/releases/pr3161.htm].

Sachs, Jeffrey. 1995. Do we need an international lender of last resort? Frank D. Graham lecture, Princeton University. 20 April.

Schneider, Martin, and Aaron Tornell. 2000. Balance sheet effects, bailout guarantees, and financial crises. NBER Working Paper no. 8060. Cambridge, Mass.: National Bureau of Economic Research.

Thornton, Henry. [1802] 1978. An enquiry into the nature and effects of the paper credit of Great Britain. Reprint, Fairfield: Augustus M. Kelley.

Tirole, Jean. 2001. Liquidity provision and the international financial system. Bank of Italy Paolo Baffi lectures on money and finance. Rome: Edizioni dell'Elefante. 


\section{Comment Olivier Blanchard}

This is an extremely nice paper. It has two parts, a model of multiple equilibria based on maturity/currency mismatch, and a discussion of the role for a lender of last resort in the context of such multiple equilibria. It has two important propositions, the first about the (near) irrelevance of monetary policy in the context of banking and currency crises, the second about the need for directed intervention by the international lender of last resort. Let me discuss each one in turn.

\section{The Maturity/Currency Mismatch Model}

The basic model presented by Jeanne and Wyplosz (JW hereafter) is beautifully simple. It is based on two relations. The first relies on the maturity/currency mismatch of bank liabilities and assets, and it implies a positive relation between expected depreciation and bank failures. The second relies on the response of policy to bank failures, and it implies a positive relation between bank failures and expected depreciation. Two positive relations open the scope for multiple equilibria, including one with high expected depreciation and high bank failures. This is precisely what the model generates.

I shall focus in what follows on the first of these two relations. First, however, let me say a few words about the second relation. JW derive it from a desire by the government, in the face of lower equilibrium output due to bank failures, to boost demand through inflation and, by implication, depreciation. This does the trick, but one can think of other channels. More likely (equally likely?) is a story in which bank failures and a sharp recession lead to a loss of fiscal control, the expectation of higher money growth, higher inflation, and larger depreciation.

Let me turn now to the first of the two relations and the effects of interest rates and the exchange rate on balance sheets.

JW focus in the text on a special case, in which banks have only shortterm dollar liabilities and long-term peso (domestic currency) assets. They are right to do so, as the results in this case are indeed striking. However, something is, I think, learned from the more general case (which they work out in the appendix, except for the presence of long-term liabilities).

Take a bank with both peso and dollar short- and long-term liabilities $\left(D_{1}, D_{1}^{*}, D_{2}, D_{2}^{*}\right)$, and assets $\left(R_{1}, R_{1}^{*}, R_{2}, R_{2}^{*}\right)$, and consequently with this balance sheet:

Olivier Blanchard is the Class of 1941 Professor and chairman of the Department of Economics at the Massachusetts Institute of Technology and a research associate of the National Bureau of Economic Research. 


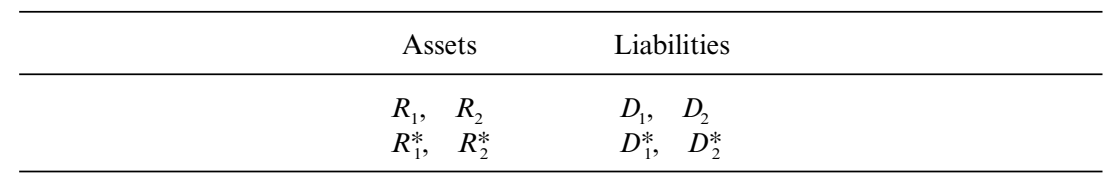

Asterisks denotes dollar assets or liabilities; 1 and 2 refer to the short and the long term respectively. Let, as in the paper, $S_{1}$ and $S_{2}^{e}$ be the current and the future expected exchange rate, expressed in dollars per peso. Then the net worth of the bank in dollars is given by

$$
N W^{*}=(\text { Terms in dollars })+\frac{S_{1}}{1+i}\left(R_{2}-D_{2}\right)+S_{1}\left(R_{1}-D_{1}\right)
$$

The second term is the value of long-term peso assets minus liabilities, discounted at the domestic interest rate, and expressed in dollars using the current exchange rate. The third term is the value of short-term peso assets minus liabilities, again expressed in dollars using the current exchange rate.

Recall that the interest parity condition is given by

$$
\frac{S_{1}}{1+i}=\frac{S_{2}^{e}}{1+i^{*}}
$$

Replacing in the previous equation implies

$$
N W^{*}=(\text { Terms in dollars })+\frac{S_{2}^{e}}{1+i^{*}}\left(R_{2}-D_{2}\right)+S_{1}\left(R_{1}-D_{1}\right)
$$

In the model presented in the text, $R_{1}, D_{1}$, and $D_{2}$ are all equal to zero. This has two implications:

- Because $D_{2}$ is equal to zero, the second term is an increasing function of the expected exchange rate. An expected depreciation decreases the net worth of banks.

- Because both $R_{1}$ and $D_{1}$ are equal to zero, the last term is equal to zero. Because the second term depends neither on the current exchange rate nor on the current domestic interest rate, then, given $S_{2}^{e}$, the interest rate-exchange rate mix does not affect the net worth of banks.

This last result is perhaps the most striking result of the JW paper. This derivation makes clear, however, that it depends on the last term's being zero, in other words, a zero short-run position in net domestic assets. If the condition is not satisfied, then monetary policy can improve the net worth of banks through manipulation of the exchange rate; whether it does this through a depreciation or an appreciation depends on the sign of the net position.

What should we expect the sign of $\left(R_{1}-D_{1}\right)$ to be in practice? The answer is far from clear. On the one hand, currency mismatch leads to a small value 
of $D_{1}$ (peso liabilities). On the other hand, maturity mismatch leads to a small value of $R_{1}$ (short-term peso claims).

This gives some perspective to the result emphasized by JW: it is indeed special, but there is no obvious bias relative to the general case.

There are other dimensions in which the JW model is special and could be misleading (JW are not guilty, as the model is just fine for the issues they focus on). Let me mention a few, more as potential extensions than as criticisms.

First, the model focuses exclusively on the banks' balance sheets. Thus, within the logic of the model, one simple way of avoiding crises is for banks to balance their dollar liabilities with dollar claims, therefore eliminating the currency mismatch from their balance sheet and removing the possibility of multiple equilibria.

Although correct in the model, this conclusion is likely to be wrong in fact: It ignores the fact that the ultimate borrowers are domestic firms, which, for the most part, get their revenues in pesos, not in dollars. Denominating bank claims in dollars merely transfers the burden from banks to firms. After a depreciation, some firms may not be able to pay back their dollar liabilities, leading in turn to bank failures.

One should not conclude from this that the denomination of bank claims is irrelevant. Firms may have deeper pockets than banks after a depreciation, so that denominating bank claims in dollars rather than pesos may actually reduce overall firms' and banks' failures. However, the argument clearly implies that the outcome is likely to depend not only on the banks' but also on the firms' net worth distribution.

Second, one can actually push the logic of the argument one more step: firms get their revenues from producing and selling goods. Their peso revenues, and therefore their ability to repay in the future, are likely to vary with the future price level. This in turn raises the issue of whether, when we look at the effect of a decrease in $S_{2}^{e}$, we are looking at a nominal or at a real expected depreciation.

To see why this matters, suppose that banks' claims on firms are stated not in pesos but in terms of domestic goods, or, equivalently, that what happens to the economy depends on the consolidated net worth of banks and firms. Let $R_{2}$ now denote revenues in terms of domestic goods and let $P_{2}^{e}$ denote the expected future price level. In this case, the present value in dollars of future claims on domestic firms is given by

$$
S_{1} \frac{P_{2}^{e} R_{2}}{1+i}=\frac{S_{2}^{e} P_{2}^{e}}{1+i^{*}} R_{2},
$$

where the equality follows from interest parity. Now assume that purchasing power parity holds in the long term, so the expected depreciation reflects higher inflation. In the notation of the JW model: $S_{2}^{e} P_{2}^{e}=$ constant. This in turn implies 


$$
\frac{S_{2}^{e} P_{2}^{e}}{1+i^{*}} R_{2}=\frac{R_{2}}{1+i^{*}}
$$

The expression is independent of the future expected depreciation, again breaking the link between expected depreciation and bank failures. Put in slightly paradoxical terms: rather than making things worse, the maturity mismatch helps here. Because the claims are long term, and because, in the long term, purchasing power parity holds, their value in dollars is independent of short-term fluctuations in the exchange rate.

Third, to focus on net worth effects, JW rightly choose to ignore issues of liquidity. Implicitly, they assume that firms can either liquidate projects for the present value of the revenues or that they have enough collateral that they can find some other lender if banks call back the loans. Neither assumption is terribly appealing, and it is interesting to think about what happens when issues of liquidity are reintroduced in the model.

Assume that, if banks call back their long-term peso claims, they get less than the present value of these claims. Assume further that the larger the proportion of claims called back, the higher the discount. This opens the door to two sources of multiple equilibria: first, the multiple equilibria that are the focus of the JW paper, each associated with a different value of $S_{2}^{e}$; and, second, for a given $S_{2}^{e}$, equilibria with and without runs on the banks. In standard fashion, a run on banks forces them to call back loans, decreasing their net worth, triggering failures, and justifying the run in the first place. Note that the lower $S_{2}^{e}$, the lower the net worth of banks in the good equilibrium, the more likely are multiple equilibria.

There is a potentially interesting twist here (this is speculative, but speculating is the privilege of the discussant), namely, the interaction between the two sources of multiple equilibria. For example, in the high $S_{2}^{e}$ equilibrium, $S_{2}^{e}$ may be high enough to rule out multiple bank run equilibria. However, in the low equilibrium, the weakened net worth position of banks may open the scope for the second type of multiple equilibria, those based on illiquidity.

\section{Directed Lending by the Lender of Last Resort}

The mismatch model allows for a precise discussion of the potential role for a lender of last resort, and I find the point emphasized by JW - namely, that such international lending should be directed and used to alleviate directly the currency/maturity mismatch for banks - very convincing and very important. Let me elaborate on two issues here.

I am less worried about moral hazard problems than the authors appear to be. I believe that lending by the international lender of last resort should be to the government, not to the banks themselves, and I do not see why the international lender has to involve itself in the details of domestic bank supervision.

In another paper, Jeanne and Zettelmeyer (2001) have shown that such 
loans are typically repaid, so the cost is borne within the country, not by international taxpayers. If the government is benevolent (i.e., it cares primarily about domestic taxpayers), then it will indeed want to use the funds for directed lending to banks, or to honor guarantees on dollar-denominated debt. Separating potentially solvent from insolvent banks will entail the usual amount of guesswork and mistakes. However, it is not clear why and how international lending to the government makes this worse.

If the government is not benevolent, but is instead captured by the banks or some of the debtor firms, then it will indeed misbehave. However, it will typically do so whether or not it can borrow from the international lender. It is not clear why, conditional on the government's having to repay the funds lent by the international lender, access to such funds will lead to a worse outcome.

I am more worried, however, about the generality of the directed-lending result.

Consider another example of multiple equilibria, which also opens the case for a potential intervention by a lender of last resort. Forget banks. Take a European Monetary System-type crisis, in which the currency is pegged. An attack on the currency, which requires high interest rates, leads to a recession and forces a devaluation, which in turn justifies the attack. In this case, it is not clear to which institutions, if any, the funds should be directed. For the reasons given in the paper, this makes intervention by a lender of last resort much more difficult and thus, other things being equal, less appealing.

This, in turn, raises at least two issues: first, whether the nature of actual crises is sufficiently identifiable that, in practice, the international lender can assess whether directed lending will work - justifying intervention - or not, in which case it may not want to lend; second, whether the nonmismatch multiple equilibria we can think of all rely, as is the case above, on the defense of a fixed exchange rate. (All those I could think of did). If the answer is yes, then, under floating rates, the mismatch example that is the focus of the paper may be the typical case, in which case directed lending, and intervention by the international lender, can indeed be the solution.

\section{Reference}

Jeanne, Olivier, and Jeromin Zettelmeyer. 2001. International bailouts, moral hazard, and conditionality. Economic Policy 33 (October): 407-32.

\section{Discussion Summary}

Martin Feldstein inquired why, if the IMF has to go in and be a supervisor at the local level, it cannot lend directly to the government.

Morris Goldstein inquired whether the risk is even bigger when there are 
both bank and corporate mismatches. He also noted that the model's results are invariant to the exchange rate regime only if the regime in place is not relevant to the balance sheet mismatch. Supposedly, a floating regime can deter the creation of this mismatch in the first place.

Jeffrey Shafer questioned the "interest rates don't matter" conclusion. $\mathrm{He}$ mentioned the Mexico crisis as a case in which the interest rate played a key role when policy tightened and the money supply was restricted.

Robert P. Flood questioned whether UIP couldn't hold in this model.

Peter B. Kenen stated that, even with a floating exchange rate regime, government debt is still a major problem. Thus, not only bank debt matters. Olivier Jeanne's model, he noted, corresponds to the Meltzer commission's view of the world. However, because the IMF lends money to the government and not the banks that are experiencing a mismatch crisis, there is a principal-agent problem involved. Then, an international supervisor of national supervisors is needed.

Stijn Claessens inquired whether the model implied that the lender-oflast-resort (LOLR) function is only relevant for twin crises, and asked if the model implies that an LOLR is not helpful in a classical balance-ofpayments crisis.

Andrew Berg pointed to portfolio balanced effects and their consequences for stabilization programs when capital is mobile. He also questioned the relevance of the model to the Mexican crisis, as investors were fleeing all banks, not only some subset with weaker fundamentals.

Michael P. Dooley inquired whether a LOLR could function if it does not have the power to nationalize the banking industry.

Barry Eichengreen asked whether the banks would not be able to borrow abroad when hit by a liquidity crisis, given the assumptions of the model, and whether this left any need for a LOLR.

Olivier Jeanne's response focused first on the applicability of the model to the LOLR function. He noted that whether the mismatch is in the banking or corporate sector (or both) is not a problem as long as by lending to banks the LOLR solves the problem. He then, in response to Eichengreen's comment, noted that in the bad equilibrium banks are really insolvent and cannot borrow abroad - provided they had a currency mismatch in the first place. He also remarked that it is not easily seen why domestic governments cannot supply the LOLR function. An international LOLR faces a moral hazard problem in its relationship with the domestic authorities. It may need, as a result, to supervise the domestic supervisors - which is possible, in practice, only if it does some supervising of banks directly. He concluded by noting that the result that "the interest rate does not matter in a crisis" corresponds to an interesting but special case of the model. In general the interest rate matters. It could matter, furthermore, for reasons that are not in the model. For example, in a signaling framework (such as Drazen's), the government could raise the interest rate in order to signal its type. 